\title{
RESEPSI REMAJA PEREMPUAN PEMBACA NOVEL POPULER
}

\author{
Tania Intan \\ Departemen Susastra dan Kajian Budaya, \\ Fakultas Ilmu Budaya, Universitas Padjadjaran \\ tania.intan@unpad.ac.id
}

\begin{abstract}
Abstrak
Fakta bahwa perempuan lebih banyak membaca novel dibandingkan dengan laki-laki dilatarbelakangi oleh konstruksi keluarga dan masyarakat yang cenderung menempatkan perempuan pada ranah domestik. Penelitian ini dilakukan untuk mendiskusikan resepsi remaja perempuan pembaca novel populer. Pendekatan yang digunakan adalah resepsi sastra. Objek penelitian adalah hasil angket yang didistribusikan pada dua puluh lima responden remaja perempuan pembaca novel populer, yang merupakan siswi kelas VIII di SMP Negeri 2 Bandung. Responden dipilih dengan teknik purposive sampling. Data dianalisis secara deskriptif dengan teknik simak dan catat. Hasil penelitian menunjukkan bahwa remaja perempuan pembaca novel populer memahami perbedaan novel populer dengan novel sastra. Setelah membaca, mereka membahas hasil bacaannya dengan teman. Tujuan remaja perempuan membaca novel populer adalah untuk mengisi waktu senggang dan juga memperoleh hiburan (enjoyment). Kebiasaan mereka membaca didorong oleh keinginan pribadi dan sebagian dipengaruhi oleh lingkungannya. Membaca novel populer juga dianggap menambah wawasan (self-development) mereka. Karena responden berada pada tahap remaja awal dan cenderung berkarakter kanak-kanak, genre novel populer yang paling disukai adalah misteri, petualangan, dan sedikit percintaan. Peneliti menyarankan agar remaja perempuan diperkenalkan pada beragam jenis bacaan untuk memperkaya wawasan.
\end{abstract}

Kata kunci: resepsi, remaja perempuan, pembaca, novel populer

\begin{abstract}
The fact that women read more novels than men is motivated by the construction of family and society which tends to place women in the domestic realm. This research was conducted to discuss the reception of teenage girls reading popular novels. The approach used is a literary reception. The object of the research was the results of a questionnaire distributed to twentyfive female respondents who were popular readers of novel novels, who were eighth grade students at SMP Negeri 2 Bandung. Respondents were selected by purposive sampling technique. Data were analyzed descriptively by listening and note taking techniques. The results showed that teenage girls who read popular novels understood the differences between popular novels and literary novels. After reading, they discuss the results of their reading with friends. The purpose of teenage girls reading popular novels is to fill leisure time and also get entertainment (enjoyment). Their reading habits are driven by personal desires and partly influenced by their environment. Reading popular novels is also considered to add insight (selfdevelopment) them. Because they are in their early teens and tend to be of childish character, the most popular genre of popular novels is mystery, adventure, and a little romance.
\end{abstract}


Tania Intan

Researchers suggest that teenage girls should be introduced to various types of readings to enrich insight.

Keywords: reception, teenage girl, reader, popular novel

\section{PENDAHULUAN}

Pembicaraan tentang remaja dan hubungannya dengan karya sastra tidak terlalu sering ditemukan. Padahal menurut Santrock (2012) yang dikutip Rahmaningsih \& Martani (2014: 179), masa remaja adalah masa krusial bagi perkembangan individu, sebab pada masa ini, individu mengalami transisi biologis, kognitif, maupun sosial-emosional. Akibatnya, individu mulai mencaricari identitas dan memahami dunia dengan caranya sendiri. Apa yang dilakukan remaja saat masa pencarian ini, termasuk apa yang mereka baca, dalam pandangan Udasmoro (2014: iii) berkaitan dengan konstruksi identitas yang sesuai dengan cara dan harapan mereka meskipun ada kendali atau konstruksi lain yang ketat dari lingkungannya.

Hill (dalam Steinberg, 2011) yang dikutip Rahmaningsih \& Martani (2014: 180) mengaitkan situasi ini pada penggunaan waktu luang yang merupakan konteks yang berkontribusi terhadap perkembangan psikososial remaja. Kegiatan membaca sebagai hobi yang umumnya ditekuni remaja berkaitan dengan tujuan memperoleh hiburan. Bacaan fiksi merupakan media yang tepat untuk meningkatkan minat baca, sebab jenis bacaan tersebut menyajikan cerita, berbeda dengan buku pelajaran sekolah atau pun buku teori.

Rahmaningsih \& Martani (2014: 180) menyepakati gagasan Baran (2006) bahwa buku merupakan jenis media massa yang berfungsi sebagai sumber pengembangan diri dan cenderung mendorong refleksi pribadi yang lebih besar bila dibandingkan dengan jenis media lainnya. Bacaan yang disukai kalangan remaja umumnya adalah karya sastra atau novel populer. Karya semacam ini tidak menampilkan permasalahan kehidupan yang intens dan tidak berusaha meresapi hakikat kehidupan. Sebab jika demikian, novel populer akan menjadi berat dan berubah menjadi sastra serius yang boleh jadi akan ditinggalkan oleh pembacanya (Nurgiyantoro, 2005: 18).

Pada awalnya, menurut Sari (2018: 14), novel populer dianggap tidak penting dan tidak bermanfaat bagi perkembangan penulisan sastra. Kata populer yang identik dengan merakyat dianggap rendah, tidak indah, dan bahkan salah. Namun dalam perkembangannya, jenis tulisan seperti itu tidak dapat dikesampingkan dalam perbincangan sastra Indonesia modern karena jumlahnya yang terus meningkat. Pada terbitan novel-novel populer tahun 2000an menurut Adji (2017: 33), terdapat beberapa genre (label) novel yang cukup dominan, di antaranya teen literature (lebih dikenal dengan nama teen lit), chick literature (atau chick lit), metropop, dan novel remaja islami. Selanjutnya bermunculan label novel motivasi.

Purnamasari (2013: 4) mengutip Rahmawati (2012) yang berargumentasi bahwa ada hubungan positif antara kebiasaan membaca dan pemahaman bacaan. Membaca merupakan sarana yang tepat untuk membangun konsep, mengembangkan pembendaharaan kata, memberi pengetahuan, menambah 
proses pengayaan pribadi, mengembangkan intelektualitas, membantu memahami masalah orang lain, mengembangkan konsep diri, dan juga sebagai suatu kesenangan. Bila seseorang telah menyadari keuntungan dari aktivitas membaca, ia dapat menjadikannya sebagai kebiasaan. Tampubolon (1990: $227-$ 228) menjelaskan bahwa terbentuknya kebiasaan tidak dapat terjadi dalam waktu singkat, namun melalui proses yang relatif panjang. Selain waktu, faktor keinginan, motivasi, dan lingkungan juga sangat berperan. Dalam proses pembentukan kebiasaan membaca, ada dua aspek yang perlu diperhatikan, yaitu minat (perpaduan antara keinginan dan motivasi) serta keterampilan membaca.

Estetika resepsi menurut Pradopo (2002 : 108) adalah metode penelitian kritik pragmatik, yaitu penelitian sastra yang menitikberatkan peranan pembaca sebagai penyambut dan penghayat karya sastra. Kajian ini mendasarkan diri pada teori bahwa karya sastra sejak terbitnya selalu mendapat resepsi atau tanggapan para pembaca. Paradigma ini beranggapan bahwa suatu karya sastra tidak memiliki makna apapun tanpa penerimaan dari pembacanya. Saraswati (2011: 158) menjelaskan bahwa dalam kegiatan membaca, mereka tidak dalam keadaan pasif namun aktif menafsirkan isi buku tersebut. Herlina dkk. (2013: 89) kemudian memaparkan pandangan Pradopo (2002) yang menyepakati gagasan Jauss (1997), bahwa resepsi berkaitan dengan haorizon harapan pembaca. Horizon harapan adalah konsep atau pengertian tertentu yang telah dimiliki pembaca tentang sebuah karya sastra. Itulah sebabnya, tanggapan atas suatu karya dapat berbeda-beda, yang ditentukan oleh latar belakang pendidikan, pengalaman, pengetahuan, dan kemampuannya dalam menanggapi karya sastra.

Kenyataan yang menarik terungkap dari berbagai penelitian yang ditemukan Laorena (2012: 2), yaitu bahwa perempuan lebih banyak atau lebih sering membaca novel daripada laki-laki. Salah satu penyebabnya adalah sosialisasi primer yang didapatkan anak perempuan dari keluarganya. Individu akan belajar menyesuaikan diri dengan lingkungannya, misalnya jika ibu gemar membaca, maka individu akan melakukan hal yang sama hingga dewasa. Faktor lainnya, yaitu adanya dorongan orang tua untuk membiasakan anak perempuan tinggal di dalam rumah, dalam ranah domestik, dan kegiatan yang biasanya dianjurkan bagi mereka adalah membaca. Jenis bacaan yang mudah didapatkan dan easy reading 'tidak sulit dibaca' dalam hal ini tentunya merujuk pada novel fiksi populer.

Dengan mengutip Stokmans (2003), Laorena memaparkan tiga hal yang membuat seseorang membaca bacaan fiksi. Pertama adalah self-development (pengembangan diri), yang berhubungan dengan sikap pembaca yang membaca bacaan fiksi untuk mencari pengetahuan tentang cara meraih kesuksesan, cara menjalani kehidupan, atau untuk mengetahui cara menghadapi orang lain. Alasan kedua adalah enjoyment (kesenangan), yaitu berhubungan dengan sikap pembaca yang membaca bacaan fiksi untuk memasuki dunia baru (lain) dan mendapatkan pengalaman dari cerita petualangan yang ada dalam bacaan fiksi tersebut. Alasan ketiga adalah escape (pelarian), yang berhubungan dengan sikap 
pembaca yang membaca bacaan fiksi sebagai pengalihan atau hiburan untuk melupakan masalah yang sedang dihadapi.

Dengan latar belakang dan kerangka pemikiran yang telah dipaparkan di atas, penelitian ini akan berfokus pada resepsi remaja perempuan pembaca novel populer. Permasalahan penelitian yang telah diidentifikasi adalah: profil remaja perempuan pembaca novel populer; motivasi bagi remaja perempuan membaca novel populer; serta jenis novel populer dan penulis favorit.

Penelitian terdahulu yang telah dilakukan berkaitan dengan resepsi perempuan remaja di antaranya: Dinamika Konsep Diri pada Remaja Perempuan Pembaca Teenlit yang dilakukan Rahmaningsih \& Martani (2014). Selain itu, Sari (2018) juga telah mengkaji Resepsi Anak Usia SMP terhadap Novel Teenlit yang Berjudul Dalam Rinai Hujan Karya Arie Saptadji. Sedangkan Laorena (2012) telah menelaah Makna Novel dalam Kehidupan Sehari-hari Para Pembaca Perempuan.

\section{METODE PENELITIAN}

Fokus dari penelitian ini adalah resepsi remaja perempuan pembaca novel populer, sehingga pendekatan yang digunakan adalah resepsi sastra dengan metode penelitian deskriptif. Responden terdiri dari 25 orang remaja perempuan yang dipilih secara acak dari siswi kelas XVIII di SMPN II Bandung. Seluruhnya memenuhi kriteria dan sesuai dengan variabel penelitian ini, yaitu: perempuan, remaja berusia 12-14 (masa remaja awal), dan merupakan pembaca [aktif] novel populer.

Mereka dipilih melalui teknik purposive sampling, yaitu teknik yang digunakan peneliti jika memiliki pertimbangan-pertimbangan tertentu dalam pengambilan sampelnya (Idrus, 2009: 96).

Objek penelitian berupa hasil angket yang disusun oleh peneliti, dan terdiri dari 15 pertanyaan berkaitan dengan resepsi remaja perempuan pembaca novel populer; tujuan membaca novel populer; serta jenis novel dan penulis favorit. Pengisian angket dilakukan selama dua minggu, yaitu dari tanggal 1 sampai dengan 15 Agustus 2019.

Data yang telah terkumpul kemudian dianalisis melalui beberapa tahapan. Pada mulanya, data-data diorganisasikan dan disusun secara sistematis. Setelah dipahami, pada data tersebut dilakukan analisis awal dengan cara pemadatan dan penentuan kata kunci. Kemudian temuan dari tahap ini dikaji dengan teori-teori yang relevan. Landasan teoretis yang digunakan untuk mengkaji di antaranya teori tentang membaca yang dikemukakan Escarpit, tentang resepsi sastra dari Pradopo dan Jauss, serta motivasi membaca dari Stockmans.

\section{HASIL DAN PEMBAHASAN}

Pada bagian hasil penelitian dan pembahasan ini, pertama-tama akan dibahas resepsi remaja perempuan pembaca novel populer yang menjadi responden. Kemudian dipaparkan tujuan, manfaat, dan motivasi membaca novel populer menurut remaja perempuan pembaca novel populer. Bagian terakhir menguraikan bahasan mengenai genre novel populer dan penulis 
favorit responden. Sistematika ini disesuaikan dengan urutan pertanyaan pada angket yang telah didistribusikan.

\section{Resepsi Remaja Perempuan Pembaca Novel Populer}

Setelah mengisi bagian identitas, responden menjawab pertanyaan pertama pada angket mengenai definisi novel populer. Pertanyaan ini perlu diajukan untuk memeriksa pemahaman para responden mengenai karakteristik novel populer, yang membedakannya dengan novel sastra 'kanonik'. Kata-kata kunci yang menandai jawaban mereka adalah: sering dibaca oleh orang (12 jawaban), terkenal (8 jawaban), banyak diminati (3 jawaban), penambah wawasan (2 jawaban), karangan yang dibuat sebagai hiburan, sedang booming, memiliki rating tinggi, banyak mendapat penghargaan, dan memiliki alur cerita yang baik.

Pertanyaan kedua berkaitan dengan frekuensi membaca novel populer. Sering atau tidaknya responden membaca menunjukkan tingkat keaktivan mereka. Sembilan belas orang menjawab 'ya' atau sering membaca, dengan alasan sebagai hiburan, untuk mengisi waktu luang, menyenangkan, karena novel memiliki amanat yang bagus, karena saran dari teman, dan karena hobi. Enam orang menjawab 'tidak', baik tanpa alasan, maupun karena merasa tidak terlalu gemar membaca, tidak selalu dapat menemukan buku populer, dan hanya membaca di waktu tertentu. Hal ini dianggap kontradiktif dan menjadi catatan tersendiri, karena pada saat peneliti membagikan angket, seluruh responden ini menyatakan diri sebagai pembaca aktif novel populer.

Berkelindan dengan frekuensi aktivitas membaca mereka, pertanyaan berikutnya dibuat untuk mengetahui waktu para responden ini membaca novel populer. Lima belas orang menjawab setiap kali ada waktu luang, tujuh orang menjawab sesekali saja, dua orang menjawab setiap hari dengan alasan setiap kali akan tidur harus membaca, dan satu orang tidak menjawab.

Bila selesai membaca novel populer, empat belas orang responden menyatakan selalu membahasnya dengan orang lain yaitu teman, tujuh orang tidak membahasnya, dan empat orang tidak menjawab. Tindakan 'membahas' atau mendiskusikan buku yang telah dibaca dengan teman-teman merupakan bentuk resepsi aktif yang dilakukan remaja perempuan. Perbincangan ini dapat dianggap sebagai kajian yang relatif kritis, cetusan dan pernyataan rasa suka atau tidak suka, dan ungkapan argumentasi atas pilihannya tersebut.

Selain membaca novel populer, delapan responden menyatakan memiliki hobi lain, seperti: menggambar (sepuluh orang), berenang (enam orang), memasak, bermain musik, menulis cerita, memotret, satu orang tidak menemukan hobi lain selain membaca, dan satu orang tidak menjawab. Realita ini menunjukkan bahwa sekalipun mereka gemar membaca, tidak berarti para remaja perempuan ini meninggalkan kegemaran lainnya. Mereka tetap aktif menekuni kesukaan masing-masing yang berkaitan dengan aktivitas fisik.

Dari pembahasan ini, dapat dirumuskan bahwa responden yang menjadi representasi dari remaja perempuan pembaca novel populer ini memahami makna novel populer, yaitu sering dibaca oleh orang, terkenal, dan 
banyak diminati. Frekuensi kegiatan membaca cukup tinggi, selain karena alasan untuk mengisi waktu luang dan menjadi hiburan, mereka menganggap membaca adalah hal yang menyenangkan. Pada umumnya, mereka membaca setiap kali ada waktu luang. Karena ada keterikatan emosional dan ketertarikan pada bacaan, mereka cenderung membahasnya dengan teman [yang memiliki kegemaran serupa]. Ternyata, meskipun para responden hobi membaca, sebagian besar memiliki hobi lain.

Tabel berikut ini memaparkan profil perempuan remaja pembaca novel populer yang direpresentasikan oleh para responden.

\section{Tabel 1}

Resepsi Perempuan Remaja Pembaca Novel Populer

\begin{tabular}{ll}
\hline $\begin{array}{l}\text { Memahami makna } \\
\text { novel populer }\end{array}$ & $\begin{array}{l}\text { Karangan yang dibuat sebagai hiburan, penambah } \\
\text { wawasan, sering dibaca oleh orang, terkenal, } \\
\text { banyak diminati, sedang booming, memiliki rating } \\
\text { tinggi, banyak mendapat penghargaan, dan } \\
\text { memiliki alur cerita yang baik. }\end{array}$ \\
\hline $\begin{array}{l}\text { Frekuensi membaca } \\
\text { novel populer }\end{array}$ & $\begin{array}{l}\text { Sering membaca dengan alasan: sebagai hiburan, } \\
\text { untuk mengisi waktu luang, menyenangkan, } \\
\text { karena novel memiliki amanat yang bagus, karena } \\
\text { saran dari teman, dan karena hobi. }\end{array}$ \\
\hline $\begin{array}{l}\text { Waktu membaca } \\
\text { novel populer }\end{array}$ & Setiap kali ada waktu luang \\
\hline $\begin{array}{l}\text { Kegiatan setelah } \\
\text { membaca novel } \\
\text { populer }\end{array}$ & Membahasnya dengan teman \\
\hline $\begin{array}{l}\text { Hobi selain } \\
\text { membaca novel } \\
\text { populer }\end{array}$ & $\begin{array}{l}\text { Memasak, menggambar, berenang, bermain musik, } \\
\text { menulis cerita, memotret }\end{array}$ \\
\hline
\end{tabular}

\section{Tujuan, Motivasi, dan Manfaat Membaca Novel Populer}

Di antara pilihan untuk mengisi waktu senggang, memperoleh hiburan, mengikuti teman, dan sebagai tugas sekolah, delapan belas responden menjawab tujuan mereka membaca novel populer adalah untuk mengisi waktu senggang. Enam responden, menyatakan untuk memperoleh hiburan dan satu orang tidak menjawab.

Mengenai kebiasaan membaca novel populer, lima belas responden menyatakan tidak ada yang memberi contoh dari sekitar yang berarti suka dengan sendirinya. Enam responden menunjuk teman sebagai contoh yang membuat mereka terbiasa membaca novel populer, tiga responden terpengaruh oleh saudaranya, dan satu responden tidak menjawab. Dalam konteks ini, ternyata tidak ada pengaruh atau contoh dari orang tua, ataupun tugas dari sekolah yang sebenarnya dapat menjadi pemicu remaja untuk gemar membaca. Mereka tidak dikonstruksi oleh lingkungannya agar gemar membaca.

Menurut delapan belas responden, manfaat dari membaca novel populer adalah menambah wawasan, lima orang menjawab agar menjadi lebih gaul, dan dua orang tidak memberi jawaban. Tidak ada yang menjawab pilihan 
lain yang ada pada angket ini yaitu lebih dewasa, lebih pintar, lebih mudah berteman.

Dari hasil paparan di atas, terungkap bahwa tujuan dari para responden membaca novel populer terutama adalah untuk mengisi waktu senggang dan juga memperoleh hiburan (enjoyment). Kebiasaan mereka membaca pun didorong oleh keinginan pribadi dan hanya sebagian kecil yang dipengaruhi oleh lingkungannya. Para responden mengakui bahwa membaca novel populer menambah wawasan (self-development) mereka.

Tabel 2 berikut ini menguraikan tujuan, motivasi, dan manfaat membaca novel populer menurut para responden.

\section{Tabel 2}

Tujuan, Motivasi, dan Manfaat Membaca Novel Populer

\begin{tabular}{ll}
\hline $\begin{array}{l}\text { Tujuan Membaca } \\
\text { Novel Populer }\end{array}$ & $\begin{array}{l}\text { Untuk mengisi waktu senggang dan memperoleh } \\
\text { hiburan. }\end{array}$ \\
\hline $\begin{array}{l}\text { Motivasi Membaca } \\
\text { Novel Populer }\end{array}$ & $\begin{array}{l}\text { Tidak ada yang memberi contoh dari sekitar, suka } \\
\text { membaca dengan sendirinya. Ada pengaruh yang } \\
\text { datang dari teman dan saudara. }\end{array}$ \\
\hline $\begin{array}{l}\text { Manfaat Membaca } \\
\text { Novel }\end{array}$ & Menambah wawasan dan menjadi lebih gaul. \\
\hline
\end{tabular}

\section{Genre Novel Populer dan Penulis Favorit}

Berkaitan dengan bahan bacaan dan genre novel populer yang paling mereka sukai, responden menjawab secara cukup beragam. Empat belas responden menjawab novel misteri sangat disukai karena menyenangkan, semangat membaca, seru, dan mengasah otak. Tujuh orang menjawab novel petualangan karena menyenangkan dan membuat mereka lebih kritis dan teliti. Tiga orang menjawab novel romantis remaja (teen lit) karena ingin terbawa suasana dan menyenangkan. Satu orang menjawab novel science-fiction karena realistis. Karena masih berada pada tahap remaja awal, minat pada karir, pacaran, dan eksplorasi identitas para responden ini belum tampak secara utuh. Meskipun telah muncul ketertarikan pada relasi percintaan, namun belum benar-benar diakui. Kecenderungan mereka masih seperti anak-anak yang menyukai permainan dan petualangan. Hal ini sejalan dengan hasil penelitian Laorena (2012: 16) yang menyatakan bahwa, "pembaca perempuan berusia remaja (teenage girls reader) memang menyukai kegiatan membaca sejak anakanak dan meneruskan kebiasaan ini saat remaja. Bacaan yang disukai pada masa ini adalah cerita petualangan, fiksi sejarah/ilmiah, misteri dan romantis."

Penulis favorit yang disebutkan responden sangat beragam, mulai dari Mellyana (pengarang novel romantis genre Islam), Tisa T.S (karena bukunya sangat disukai), Tere Liye (karena bahasa yang digunakan ringan dan mudah dimengerti), Luluk H.F, Your Kidlee (karena di novelnya dia menceritakan kehidupan anak muda), Andrea Hirata (memiliki selera humor dan lelucon yang menarik), Muthia (karena novelnya selalu seru), dan Habiburrahman el Shirazy (karena novelnya menginspirasi). Resepsi remaja perempuan terhadap novel populer tidak dapat 
dilepaskan dari pengarang buku tersebut. Tanggapan positif terlihat dari penilaian 'bahasa ringan', 'mudah dimengerti', 'selera humor baik', 'novelnya seru', dan 'menginspirasi'. Hal ini menunjukkan bagaimana para responden menyukai bacaannya, dan ada kesesuaian di antara horizon harapan dengan realita bahwa 'bukunya sangat disukai'.

Beberapa nama penulis yang muncul dari angket ini telah sangat dikenal publik secara luas. Mellyana adalah penulis novel Dear Imamku (2018). Tisa T.S dikenal dengan karyanya Magic Hour \#1 (2014), London Love Story (2015), dan Promise: this in not only about love (2016). Tere Liye sendiri merupakan penulis yang sangat terkenal dan produktif, ia telah menulis di antaranya \#AboutLove (2016) dan \#AboutFriends (2017), serta Ceros dan Batozar (2018). Luluk H.F adalah penulis novel Mariposa (2016) dan Delov (2013). Your Kiddle menulis Einstein. Penulis Andrea Hirata telah banyak menulis novel best-sellers seperti Laskar Pelangi (2005) dan Edensor (2007). Sedangkan Muthia adalah penulis muda berusia 16 tahun yang telah mendapat penghargaan dan menerbitkan 12 novel, 17 buku kompilasi, 2 komik, 2 buku cerita, dan 2 artikel. Habiburrahman el Shirazy pun telah sangatr terkenal dengan novel-novel bernuansa islami dan beraliran sastra moralis, seperti: Ayat-ayat Cinta (2004), Di atas Sajadah Cinta (2004), dan Bumi Cinta (2010).

Judul-judul novel populer yang disukai para responden remaja perempuan ini adalah Dear Imam (karena mengisahkan tentang imam hidup yang baik), London Love Story (karena menarik dan sedih), Edisi Novel Bumi (karena novel tersebut mudah dipahami dan membuat terbawa suasana), Mariposa (karena lucu), Einstein (karena menceritakan kegiatan anak SMA yang juga di dalamnya terdapat kisah romantis dan kejadian lucu), To Kill A Mockingbird (memiliki pesan moral yang paling membekas untuk pembacanya), Little Ballerina (karena novelnya sangat seru), Bumi Cinta (karena pembawaan dan kata-katanya bagus). Yang dapat dicatat dari data ini, adalah pemilihan penulis favorit didasari oleh kesukaan responden pada novel favorit yang telah dibacanya.

Judul novel populer yang paling ingin dibaca para responden tapi belum didapatkan adalah Alwi Assegaf part part 2 (karena belum ada waktu untuk membelinya), Magic Hour, I fly From (karena saya suka sekali filmnya), lanjutan dari Komet Minor yaitu Nebula (karena belum dipublikasikan), Mariposa (karena belum ada uangnya), A Brief History of Time (karena memuat cerita sains yang menarik), Sejarah Al Fatih (karena novel itu seperti seru), dan Daun yang jatuh tak pernah membenci angin (judul yang menarik). Ketertarikan remaja perempuan untuk membaca buku-buku tertentu dalam konteks resepsi sastra berkaitan dengan horizon harapan mereka terhadap buku-buku tersebut. Dari judul-judul yang dipaparkan di atas, terungkap bahwa horizon harapan ini berkaitan dengan ketertarikan pada judul, pada isi cerita, dan karena merupakan lanjutan atau mengait pada buku atau film yang dianggap menarik.

Pemilihan judul novel favorit dan yang paling ingin dibaca tapi belum didapatkan menunjukkan setidaknya ada tiga kategori novel populer yang disukai remaja perempuan responden penelitian ini. Pertama adalah kategori sastra moralis/motivasi/islami yang direpresentasikan oleh Sejarah Al Fatih, Alwi Assegaf, Dear Imam, dan Bumi Cinta. Kategori kedua adalah sastra romantis remaja seperti Magic Hour, I fly from, Mariposa, London Love Story, Einstein, dan 
Little Ballerina. Kategori ketiga adalah genre petualangan dan science-fiction yang diwakili oleh Kill A Mockingbird, A Brief History of Time, dan Nebula.

Sedangkan judul novel populer yang paling tidak disukai responden adalah yang bergenre Korea seperti BTS, Dilan (karena tebal), novel bergenre percintaan (karena sangat tidak mendidik, lebih suka novel misteri), Ini bukan Dilan (karena garing), dan The Broken Wings (walaupun memang novel yang puitis tapi katakatanya terlalu berbelit-belit). Dua responden menjawab tidak ada yang tidak disukai. Dari bagian ini dapat disimpulkan bahwa [ternyata] remaja perempuan tidak [seluruhnya] menyukai novel populer yang bergenre Korea, berukuran tebal, bergenre percintaan -meskipun pernyataan ini meragukan dan di luar dugaan-, dinilai 'garing' atau tidak lucu, dan ceritanya berbelit-belit. Yang menarik, para responden dalam percakapan informal menyatakan gemar menonton drama Korea dan menonton klip video lagu Korea, namun tidak begitu suka membaca buku tentang artis Korea.

Delapan belas orang responden menyatakan mengakses atau mendapatkan novel populer yang dibacanya adalah dengan cara membelinya. Lima orang membacanya saat berada di toko buku, dan dua orang mencari $e$ book di internet. Tindakan 'membeli' alih-alih menyewa, meminjam dari teman atau dari perpustakaan, menunjukkan keseriusan para remaja perempuan untuk memiliki buku yang ingin dibacanya, dan [bila mungkin] menjadikannya benda koleksi. Dengan keniscayaan mereka belum bekerja karena masih merupakan siswi SMP, mereka akan meminta uang yang dibutuhkan dari para orang tua. Hal ini menunjukkan sikap positif dan bentuk dukungan orang tua atas hobi membaca anaknya, sekalipun tidak mengontruksi anak perempuannya agar gemar membaca.

Ketika ditanya apakah mereka pernah membaca novel sastra, delapan belas responden menjawab tidak pernah. Satu orang menyatakan pernah membaca Hamlet karya Shakespeare dan enam orang tidak menjawab. Bila ditautkan pada pertanyaan pertama mengenai pengertian novel populer yang mereka pahami, dapat diketahui bahwa para responden dapat menemukan diferensiasi di antara novel populer dan novel sastra 'kanonik'. Mereka menyadari bahwa bacaan yang telah dikonsumsi memiliki tema yang tidak terlalu berat dan dapat dimengerti dengan relatif mudah.

Kajian pada permasalahan terakhir ini memperlihatkan hasil bahwa responden yang merupakan remaja memiliki kecenderungan seperti anak-anak yang menyukai permainan dan petualangan, sehingga berpengaruh pada pilihan bacaan. Mereka menyukai novel populer bergenre misteri, petualangan, percintaan, dan science-fiction. Walaupun memiliki selera bacaan yang berbedabeda, ada pola yang dapat ditelusuri menyangkut kesukaan remaja perempuan pada judul dan penulis novel populer favorit mereka. Setidaknya ada tiga kategori novel populer dan kelompok penulis yang disukai, yaitu sastra moralis/motivasi/islami, sastra romantis remaja, dan genre petualangan dan science-fiction. Pemilihan atas kategori-kategori tersebut bukan tidak mungkin bersumber dari pola pendidikan dan pengasuhan keluarga yang memberikan bobot lebih pada hal-hal yang dimaksud. 
Tabel berikut akan merekapitulasi pembahasan bagian ini.

Tabel 3

Jenis Novel Populer Favorit, Penulis Favorit, dan Judul Novel Favorit

\begin{tabular}{ll}
\hline $\begin{array}{l}\text { Jenis Novel Populer } \\
\text { Favorit }\end{array}$ & $\begin{array}{l}\text { Novel misteri, novel petualangan, novel romantis } \\
\text { remaja (teen lit), science-fiction. }\end{array}$ \\
\hline $\begin{array}{l}\text { Penulis Novel } \\
\text { Populer Favorit }\end{array}$ & $\begin{array}{l}\text { Mellyana, Tisa T.S., J.K Rowling, Tere Liye, Luluk } \\
\text { H.F, Your Kidlee, Andrea Hirata, Muthia, dan } \\
\text { Habiburrahman el Shirazy }\end{array}$ \\
\hline $\begin{array}{l}\text { Novel Populer } \\
\text { Favorit }\end{array}$ & $\begin{array}{l}\text { Dear Imam, London Love Story, Harry Potter, Edisi } \\
\text { Novel Bumi, Mariposa, Einstein, To Kill A Mockingbird, } \\
\text { Little Ballerina, dan Bumi Cinta }\end{array}$ \\
\hline
\end{tabular}

\section{PENUTUP}

Hasil kajian menunjukkan bahwa para responden yang menjadi representasi remaja perempuan pembaca novel populer ini memahami makna novel populer, yaitu sering dibaca oleh orang, terkenal, dan banyak diminati. Frekuensi kegiatan membaca mereka cukup tinggi. Selain karena alasan untuk mengisi waktu luang dan menjadi hiburan, mereka juga menganggap membaca adalah hal yang menyenangkan. Pada umumnya, mereka membaca setiap kali ada waktu luang. Karena ada keterikatan emosional dan ketertarikan pada bacaan, mereka cenderung membahasnya dengan teman [yang memiliki kegemaran serupa]. Selain memiliki hobi membaca, sebagian besar responden juga memiliki hobi lain.

Tujuan dari para responden membaca novel populer terutama adalah untuk mengisi waktu senggang dan memperoleh hiburan (enjoyment). Kebiasaan mereka membaca pun didorong oleh keinginan pribadi dan hanya sebagian kecil yang dipengaruhi oleh lingkungannya. Para responden mengakui bahwa membaca novel populer menambah wawasan (self-development) mereka.

Kajian pada permasalahan terakhir memperlihatkan kecenderungan bahwa remaja perempuan yang menjadi responden penelitian ini masih berkarakter kanak-kanak sehingga berpengaruh pada pilihan bacaan. Mereka menyukai novel populer bergenre misteri, petualangan, percintaan remaja, dan science-fiction. Walaupun memiliki selera bacaan yang berbeda-beda, ada pola yang dapat ditelusuri menyangkut kesukaan remaja perempuan pada judul dan penulis novel populer favorit mereka. Setidaknya ada tiga kategori novel populer dan kelompok penulis yang dapat ditandai, yaitu sastra moralis/motivasi/islami, sastra romantis remaja, dan genre petualangan dan science-fiction.

Dari seluruh pembahasan ini, terungkap bahwa resepsi remaja perempuan terhadap novel populer yang dibacanya bernilai positif karena dapat memenuhi kebutuhan kesenangan dan wawasan. Keragaman pilihan di antara responden juga memperlihatkan hal yang disebut Udasmoro (2014: 38) 
'keberbedaan' sebagai ciri dari masa remaja. Bacaan ini juga berimplikasi pada pembentukan karakter dan identitas sebagai remaja perempuan.

Bagaimanapun juga, penelitian ini memang belum tuntas dan masih membuka banyak celah untuk dilanjutkan. Isu-isu yang dapat dikerjakan di antaranya berkaitan dengan pembacaan atas novel-novel populer tertentu, ekranisasi novel populer, tanggapan remaja perempuan atas novel percintaan, dan lain sebagainya.

Untuk memperluas cara pandang remaja perempuan, ada baiknya pihak-pihak terkait mulai dari keluarga, sekolah, hingga komunitas yang relevan, mengkondisikan mereka untuk menambah ragam jenis bacaan. Dengan demikian, diharapkan pemaknaan pada novel populer oleh remaja perempuan tidak lagi sekedar untuk hiburan, melainkan lebih bersifat informatif dan masukan untuk pengembangan diri serta menjadi motivasi untuk menghadapi kehidupan mendatang sebagai perempuan dewasa.

\section{DAFTAR PUSTAKA}

Adji, Muhamad. 2017. Budaya Anak Muda pada Sastra Populer. Jatinangor: Unpad Press.

Idrus, M. 2009. Metode Penelitian Ilmu Sosial. Yogyakarta: PT. Gelora Akasara Pratama.

Herlina, dkk. 2013. “Novel Rumah Tanpa Jendela Karya Asma Nadia (Kajian Sosiologi Sastra, Resepsi Pembaca, dan Nilai Pendidikan)". Jurnal Pendidikan Bahasa dan Sastra. Vol. 1, No. 1. hlm. 85-96.

Laorena, Hernita Des. 2012. "Makna Novel dalam Kehidupan Sehari-hari Para Pembaca Perempuan”. Media Libri-Net. Vol.1, No. 1 Des 2012. hlm. 1-17.

Nurgiyantoro, Burhan. 2005. Sastra Anak. Pengantar Pemahaman Dunia Anak. Yogyakarta: Gadjah Mada University Press.

Purnamasari, Dewi. 2013. Hubungan antara Kebiasaan Membaca dengan

Pemahaman Bacaan Siswa Kelas VIII SMP di Kecamatan Kalasan Sleman.

Skripsi. Program Studi Pendidikan bahasa dan Sastra Indonesia.

Universitas Negeri Yogyakarta.

Rahmaningsih, Novia Dwi \& Martani, Wisjnu. 2014. “Dinamika Konsep Diri pada Remaja Perempuan Pembaca Teenlit". Jurnal Psiki. Vol. 41, No. 2, Desember 2014. hlm. 179-189

Saraswati, Ekarini. 2011. “Resepsi Estetis Pembaca Terhadap Novel Supernova karya Dee". Jurnal Atavisme. Vol. 14, No.1. Hlm. 156-169

Sari, Luluk Diana Novita. 2018. "Resepsi Anak Usia SMP terhadap Novel Teenlit yang berjudul Dalam Rinai Hujan Karya Arie Saptadji”. Jurnal Ilmiah Bahasa dan Sastra. Vol. 5, No.1 Tahun 2018. Hlm. 13-24

Tampubolon. 1990. Kemampuan Membaca (Teknik Membaca Efektif dan Efisien). Bandung: Angkasa.

Udasmoro, Wening, dkk. 2014. Konstruksi Identitas Remaja dalam Karya Sastra. Yogyakarta: Sastra Prancis Fakultas Ilmu Budaya Universitas Gadjah Mada. 